\title{
A PATAGONIAN SWAN (ANATIDAE: ANSERINAE) FROM THE UPPER PLEISTOCENE OF AUSTRAL CHACO (ARGENTINA)
}

\author{
RAÚL IGNACIO VEZZOSI (1) \\ Consejo Nacional de Investigaciones Científicas y Técnicas (CONICET), Argentina. Facultad de Ciencia y Tecnología, \\ Universidad Autónoma de Entre Ríos, Ruta Provincial N 11, Km 10,5, Oro Verde E3100XAD, Entre Ríos, Argentina. \\ vezzosiraul@gmail.com (corresponding author) \\ WASHINGTON JONES (1) \\ Programa de Desarrollo de las Ciencias Básicas (PEDECIBA). Museo Nacional de História Natural, 25 de Mayo 582, \\ 11000, Montevideo, Uruguay.wawijo@yahoo.com.ar
}

PABLO J. GAUDIOSO (1)

Consejo Nacional de Investigaciones Científicas y Técnicas (CONICET). Programa de Investigaciones de Biodiversidad Argentina (PIDBA); Facultad de Ciencias Naturales e Instituto Miguel Lillo, Universidad Nacional de Tucumán, Tucumán; Instituto de Ambiente de Montaña y Regiones Áridas (IAMRA), Universidad Nacional de Chilecito, 9 de Julio 22, F5360CKB, Chilecito, La Rioja, Argentina.pablojgaudioso@hotmail.com

\section{RUBÉN M. BARQUEZ (D)}

Consejo Nacional de Investigaciones Científicas y Técnicas (CONICET), Argentina. Programa de Investigaciones de Biodiversidad Argentina (PIDBA). Facultad de Ciencias Naturales e Instituto Miguel Lillo, Universidad Nacional de Tucumán, T4000, Tucumán, Argentina.rubenbarquez@gmail.com

\begin{abstract}
A new material of a Quaternary waterfowl is described here. The implications of this finding, in the context of the dispersal of Anatidae in the past, are discussed. The specimen consists in a partial humerus coming from the Upper Pleistocene of austral Chaco from Santiago del Estero Province, Argentina. The specimen here described belongs to the tribe Cygnini, being larger than most members of the clade. The humerus shows different size than with other members of the tribe Cygnini, being larger than the humeri referred to the Andean goose (Oressochen melanopterus), the Sheldgeese of the genus Chloephaga, the Comb Duck (Sarkidiornis sylvicola), and larger than the Ruddy Shelduck (Tadorna ferruginea). However, the humerus have several anatomical characters indicating that it belongs to a basal anserine duck. These combinations of features allow us to assign this fossil to a species of waterfowl: Coscoroba coscoroba. This finding, it context with the history of the South American Cygnini, provides new environmental interpretations associated with wetlands, which will be tested in the austral Chaco and Northern Pampa through future multi-proxy studies.
\end{abstract}

Keywords: Anseriformes bird, goose, Coscoroba coscoroba, Quaternary, South America, Santiago del Estero.

RESUMO - Um novo material de uma anátide, uma ave aquática do Quaternário, é descrito aqui. As implicações desta descoberta são discutidas, no contexto da dispersão de Anatidae no passado. O espécime consiste em um úmero parcial proveniente do Pleistoceno Superior do Chaco Austral da Província de Santiago del Estero, Argentina. A morfologia umeral examinada apresenta um tamanho diferente em relação aos de outros membros da tribo Cygnini, embora seja maior do que o úmero referido ao ganso andino (Oressochen melanopterus), "sheldgeese" do gênero Chloephaga, o pato-pente (Sarkidiornis sylvicola), e maior do que o pato-ferrugíneo (Tadorna ferruginea). No entanto, o úmero compartilha vários caracteres anatômicos indicando que ele pertence a um pato anserino basal. Essas combinações de características nos permitem atribuir esse registro fóssil a uma espécie de ave aquática, o cisne Coscoroba coscoroba. Esta descoberta, em contexto com a história dos Cygnini da América do Sul, fornecerá novas interpretações ambientais associadas às áreas úmidas, que serão testadas no Chaco Austral e no Pampa Norte por meio de futuros estudos multi-proxy.

Palavras-chaves: aves Anseriformes, ganso, Coscoroba coscoroba, Quaternário, América do Sul, Santiago del Estero. 


\section{INTRODUCTION}

Anseriformes is a large and well-known order comprising more than 150 species (approximately 43 genera) of waterfowls. This group is now widely regarded as the sister group to Galliformes, which together form Galloanserae, as the sister group to the rest of Neornithes (Mayr, 2017). The systematic classification of the Anseriformes has been disputed and revised since the recognition of this group (Carboneras, 1992; Livezey, 1996, 1997; Worthy, 2008; Liu et al., 2012). Currently, the order is divided into three extant families: Anatidae (ducks, geese, and swans), Anhimidae (screamers) and Anseranatidae (the magpie geese from Australia) (Worthy et al., 2017). However, some researchers suggest that species of the genus Dendrocygna Swainson, 1837 should be considered as an independent true family (Sun et al., 2017).

The fossil record of anatids in South America has expanded notably, although it is still relatively patchy compared to the waterfowl fauna in other regions as Europe and Australia (Mayr, 2017). Several Cenozoic anseriform ducks have been reported in different deposits from Ecuador (Cambell, 1976), Talara in Peru (Campbell, 1979), Argentina (e.g. Ameghino, 1895; Tambussi, 1998; Noriega et al., 2008, Cenizo \& Agnolin, 2010; Agnolin \& Tomassini, 2012) and Uruguay (Tambussi et al., 2005; Acosta Hospitaleche et al., 2021). Nowadays, the Middle-Late Pleistocene fossil taxa are restricted to two subfamilies of Anatidae from Argentina: Tadorninae and Anatinae (Ameghino, 1891; Tonni, 1969; Agnolin, 2006). However, the mention of an Anserinae as Coscoroba, together with the Tadorniane Sarkidiornis sylvicola Ihering \& Ihering, 1907, is reported by Ameghino (1891) from post-Pampean deposits of the Holocene (Platean Stage sensu Ameghino, 1891) of Lujan in Buenos Aires, still needs to be confirmed.

Recently, a supposed Anserinae was mentioned from the Toropí/Yupoí Formation (Upper Pleistocene) from northern Mesopotamia of Argentina (Corrientes Province, Cuaranta et al., 2019).

For the Upper Pleistocene of the austral Chaco region, several lithostratigraphic units from both principal fluvial basins are recognized, the Dulce and Northern Salado Rivers (Battaglia, 1982; Iriondo, 2010; Vezzosi et al., 2019). Some of these sequences are fossiliferous with aquatic and continental vertebrates (Frenguelli, 1920; 1932; Castellanos, 1924; Vezzosi, 2016; Vallone et al., 2017; Gaudioso et al., 2017; Vezzosi et al., 2017; Albino \& Gaudioso, 2018; Brandoni \& Vezzosi, 2019; Gaudioso et al., 2019). Along the cut banks of the Dulce River the Tasigasta, Atamisqui and Dos de Mayo geological formations crop out, as well as other fluvial lithostratigraphic units such as the Capellanía Formation (Battaglia, 1982; Iriondo, 2010), that have reported continental Pleistocene vertebrate. Several fossil remains of continental mammals, as well as few reptiles, were recovered from the upper Dulce River catchment, where the Upper Pleistocene units crop out (Chimento \& Agnolin, 2011;
Gaudioso et al., 2017; Albino \& Gaudioso, 2018); however, bird remains from these two important river basins have not yet been reported.

The aim of this contribution is to report and describe a partial humerus of a waterfowl duck-like bird from the Upper Pleistocene of the austral Chaco (Santiago del Estero Province, Argentina), and to discuss the implications of this finding in the context of dispersal of Neotropical swans during the Pleistocene.

\section{Geographic and geological setting}

The fossil comes from $10 \mathrm{~km}$ east of Las Termas de Río Hondo city, between Cañada de la Costa and Sotelo localities (27²8'42”S; 6445'16”'W), Río Hondo Department, Santiago del Estero Province, Argentina (Figure 1). The sediments of this area correspond to a Pleistocene-Holocene sequence of units that have been mentioned under different names in the literature, but without an appropriate stratigraphic systematization (Beder, 1928; Battaglia, 1982; Gramajo, 1992; Iriondo, 2010). However, Battaglia (1982) defines at the top of the Salí-Dulce Basin sand levels and in part conglomeratic, with sections with sandy silts, as part of the Capellanía Formation with a Pleistocene age. Recently Iriondo (2010) defined three lithostratigraphic units in the middledown basin of the Dulce River, the former is referred to the Upper Pleistocene (Tasigasta Formation), while the others are referred to the Middle-Upper Holocene (Atamisqui and Dos de Mayo formations). Although for these latter formations no fossil remains of vertebrate Pleistocene megafauna have reported.

A general section where the fossil comes from, between the Río Hondo dam and the Sotelillos area and around $20 \mathrm{~km}$ long, shows the following sequence: from the regular level of the river, upwards, Las Cañas Formation appears first. This unit is constituted by red and brown silty sandstones, with variable thickness between 6 and $10 \mathrm{~m}$, covered in several places by one or two levels of hardened tuff (Battaglia, 1982). This is followed by about $10 \mathrm{~m}$ of coarse to medium and fine sands, in part conglomeratic, and grey and beige fine or sandy silts. At the top of this sequence, $2 \mathrm{~m}$ of loess covers the whole region. The studied material comes from fluvial levels of coarse to medium and fine sands (Figure 1). These deposits are considered as being part of the Capellanía Formation (Battaglia, 1982), which is Upper Pleistocene (Cohen et al., 2013; ICC, 2020). Moreover, the lithological descriptions of the three Quaternary formations defined by Iriondo (2010) do not coincide with the observed lithology in the area of the finding. On the contrary, this matches with the lithology of the lower member described by Battaglia (1982) for the Capellanía Formation.

\section{MATERIAL AND METHODS}

The material under study is housed in the repository collection of the Centro de Interpretación y Conservación del Patrimonio Cultural de Santiago del Estero (Argentina) under the identification CICPSGE 20/21. 


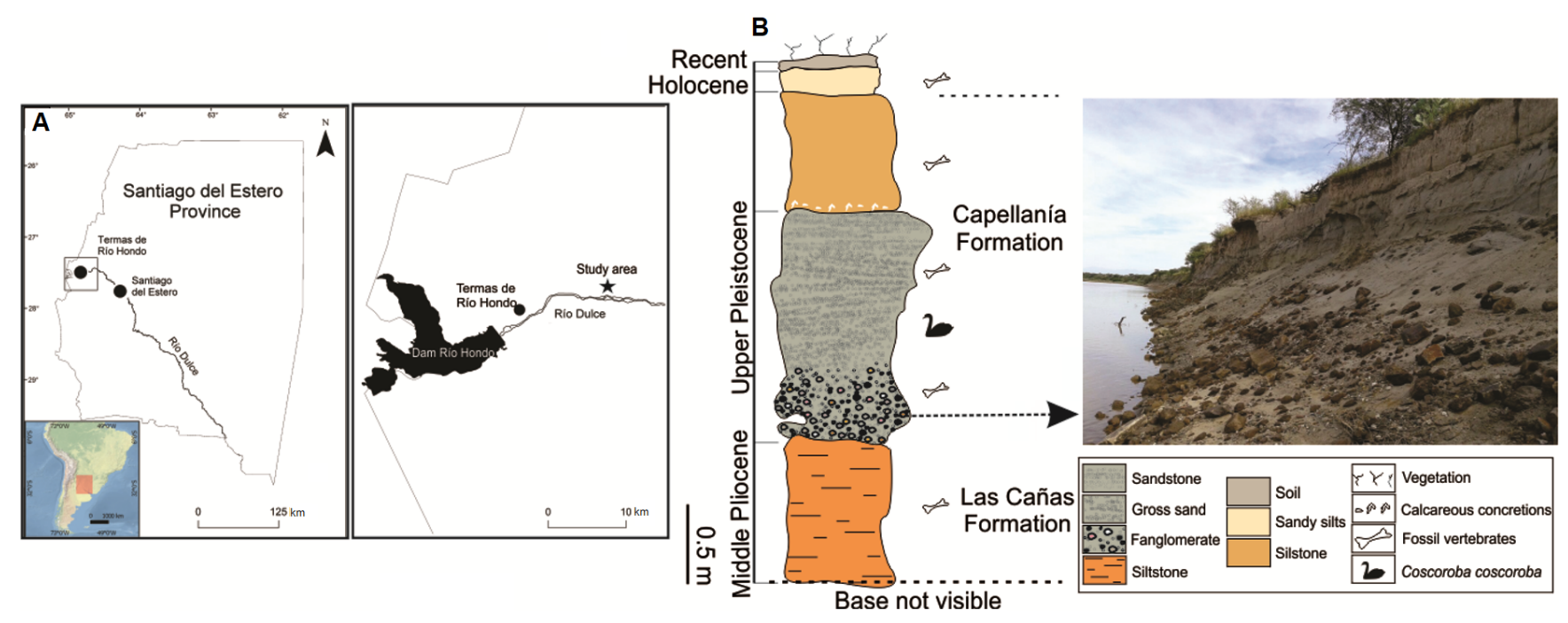

Figure 1. Location map of the fossil record of Coscoroba coscoroba from Santiago del Estero Province. A, Black star indicates the location of CICPSGE 20/21; B, lithostratigraphical sequence of Upper Pleistocene-Holocene deposits in the cliffs of Dulce river from which Coscoroba swan (CICPSGE 20/21) was recovered.

A direct comparison of the fossil specimen with the humerus of extant and extinct waterfowls Anatidae of the tribes Cygnini, Tadornini and Anatini was made. We follow the recent systematic revision done by Remsen et al. (2020) for the Anatidae Oressochen melanopterus (Eyton, 1838) (= Chloephaga melanoptera [Eyton, 1838]). Comparative osteological material of extant taxa, deposited in the ornithological collections of the Vertebrate Paleontology Laboratory, Centro de Investigación Científica y de Transferencia Tecnológica a la Producción (CICYTTP, Entre Ríos Argentina), Museo Nacional de Historia Natural de Montevideo (MNHN, Uruguay), the ornithological collection of the Fundación de Historia Natural 'Félix de Azara' (CFA-OR, Buenos Aires, Argentina) and the ornithological collection of the Smithsonian Natural History Museum (USNM, USA) were also used to aid in fossil identification.

The list of anatids specimens examined and their institutional collections is as follows: Oressochen melanopterus (CICYTTP-AAN 064), Chloephaga picta Gmelin, 1789 (CFA-OR 194, MNHN 6306), Coscoroba coscoroba (Molina, 1782) (CFA-OR 917, MNHN 7011), Sarkidiornis sylvicola (MNHN 7087), Cygnus atratus (Latham, 1790) (MNHN 6299), C. melancoryphus (Molina, 1782) (MNHN 5482), C. olor Gmelin, 1789 (MNHN 7010), Branta canadensis (Linnaeus, 1758) (USNM 343185) and Anas flavirostris Vieillot, 1816 (MNHN 6154). Comparisons with some fossil anatids taxa were based on Agnolin \& Tomassini (2012). The anatomical nomenclature of the humerus follows Baumel \& Witmer (1993) and Livezey \& Zusi (2006). Measurements were taken with a digital caliper to the nearest $0.01 \mathrm{~mm}$.

\section{SYSTEMATIC PALEONTOLOGY}

Class AVES Linnaeus, 1758

Order ANSERIFORMES (Wagler, 1831)
Family ANATIDAE Leach, 1820

Subfamily ANSERINAE Vigors, 1825

Tribe Cygnini Vigors, 1825

Coscoroba Reichenbach, 1852

Coscoroba coscoroba (Molina, 1782)

(Figures 2-3A, 4A)

Referred material. CICPSGE 20/21, distal portion of the humerus of an adult anatid swan (Figures 2-3A, 4A).

Locality and chronostratigraphy. Upper Pleistocene, levels of the lower member of Capellanía Formation (Dulce River between Cañada de la Costa and Sotelo localities, $27^{\circ} 28^{\prime} 42^{\prime \prime}$; $\left.64^{\circ} 45^{\prime} 16^{\prime \prime} \mathrm{W}\right)$, Santiago del Estero Province, Argentina.

Description and comparison. CICPSGE 20/21 does not resemble any another species of the tribes Tadornini or Anatini, and its general morphology is clearly different from that of any of the diving Anatidae. In fact, it has some characters of the tribe Cygnini, clearly recognized in the distal epiphysis of this humerus (Figures 2,3), including a tuberculum supracondylare dorsale, not forming a process as in Coscoroba coscoroba, Cygnus olor and C. melancoryphus. Moreover, this tuberculum is more conspicuous than in Sarkidiornis melanotos, Oresschen melanopterus, Chloephaga picta and in some diving ducks as Anas. Such as in Coscoroba coscoroba (CFA-OR 917, MNHN 7011), the tuberculum supracondylare dorsal is present as a shallow facet as in Cygnus spp. (Figures 2, 3). Nevertheless, this facet is elongate and shows a prominent tubercle in S. melanotos, O. melanopterus, and Ch. picta. Dorsally, it shows a shallow fovea for the attachment of the $\mathrm{m}$. pronator superficialis, with a subcircular shape as in the extant $C$. coscoroba. Although this fovea is also shallow in the species of Cygnus, it shows an enlarged shape. Whereas in O. melanopterus, S. melanotus it presents a comparatively large and deeper oval shape with a conspicuous rim, even more than in Ch. picta. 


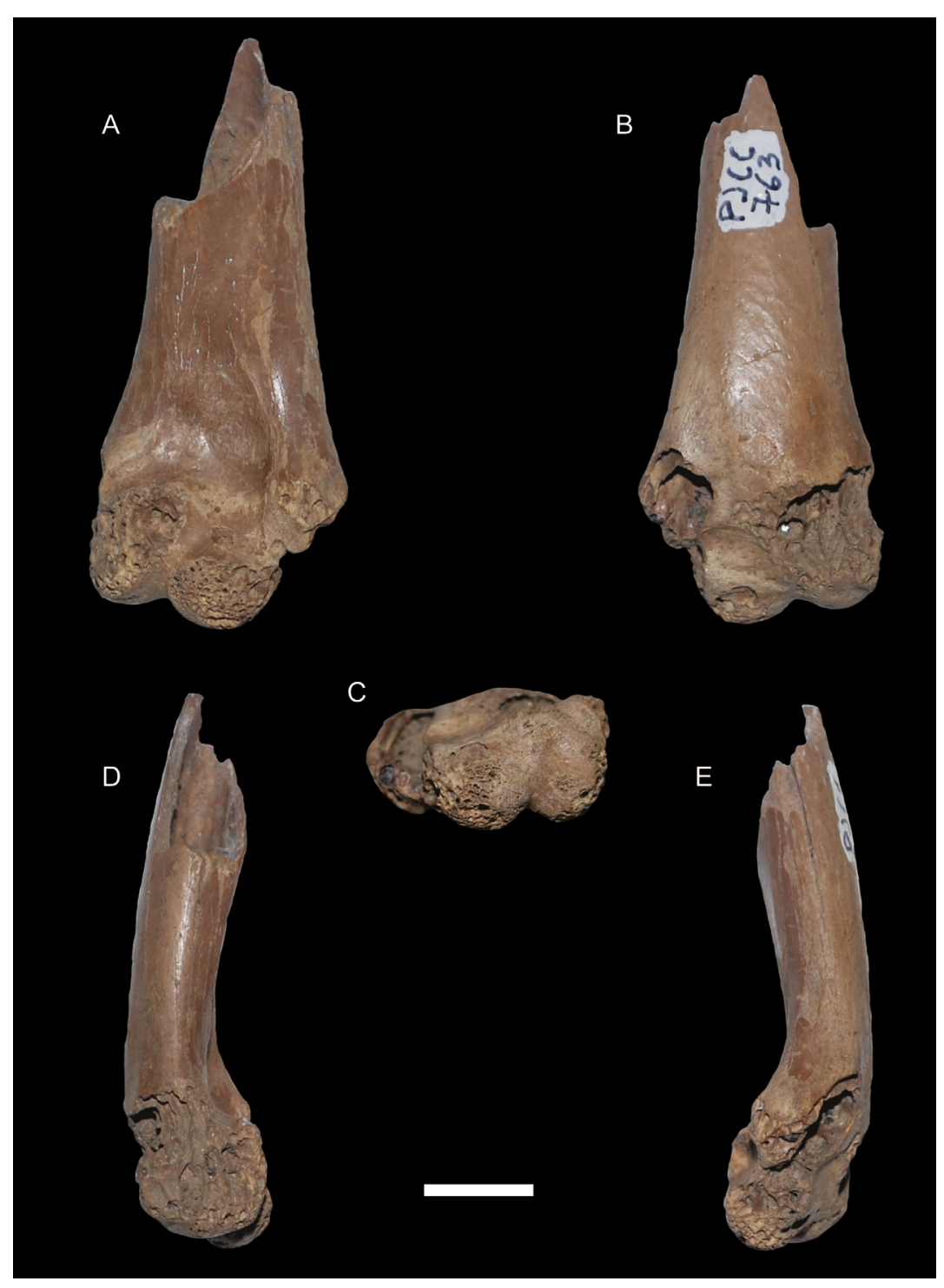

Figure 2. Humerus of CICPSGE 20/21 assigned to Coscoroba coscoroba. A, cranial view; B, caudal view; C, distal view; D, lateral view; E, medial view. Scale bar $=10 \mathrm{~mm}$.

In cranial view (Figure 2A), CICPSGE 20/21 has an oval fossa for the $\mathrm{m}$. brachialis with conspicuous rims as occurs in adult individuals of Coscoroba swan. Although all extant Cygnus spp., Oressochen melanopterus and Chloephaga picta bear a similar morphology for this fossa, but it is deeper in C. coscoroba. However, the last two taxa show a much smaller shape as observed in the majority of the Anatidae ducks as in Anas. Both condyles are similar in development and shape as in the living Coscoroba swan. Although the CICPSGE 20/21 has a more preserved ventral condyle with a subcircular shape (oval in O. melanopterus and Sarkidiornis melanotus), the preserved area of the dorsal condyle is still very similar to that of C. coscoroba (Figures 2A, 3). Between both condyles, there is a large and deep incisura intercondylaris, being shallow in O. melanopterus to not clearly distinguishable in Ch. picta. On the other hand, S. melanotus shows a larger but shallower incisura than that of the taxa compared here.
In caudal view (Figures 2B, 3A), the sulcus $\mathrm{m}$. humerotricipitalis is deep and has conspicuous rims. Although the area for the sulcus m. scapulotricipitalis is slightly fragmented, it is distally insinuated. The fossa olecrani is clearly deeper and well-developed as in all Cygnini birds, and much more than in all extant Anserinae and Dedrocygninae ducks. In distal view (Figure 4), the sulcus scapulotricipitialis is large, deep and does not extend around the tuberculum supracondylare dorsale as in Coscoroba coscoroba and Branta canadensis, while in all species of Cygnus this groove distally surrounds the dorsal condyle. Moreover, the dimensions of the humerus analyzed here are congruent with those observed in Coscoroba swan and differing from other humeral dimensions of the tribes Cygnini, Anatini and Tadornini; and being bigger than the humerus of the Andean goose O. melanopterus, the sheldgeese Chloephaga spp., the American comb duck Sarkidiornis sylvicola, and bigger than that of the shelduck Tadorna ferruginea (Table 1). 


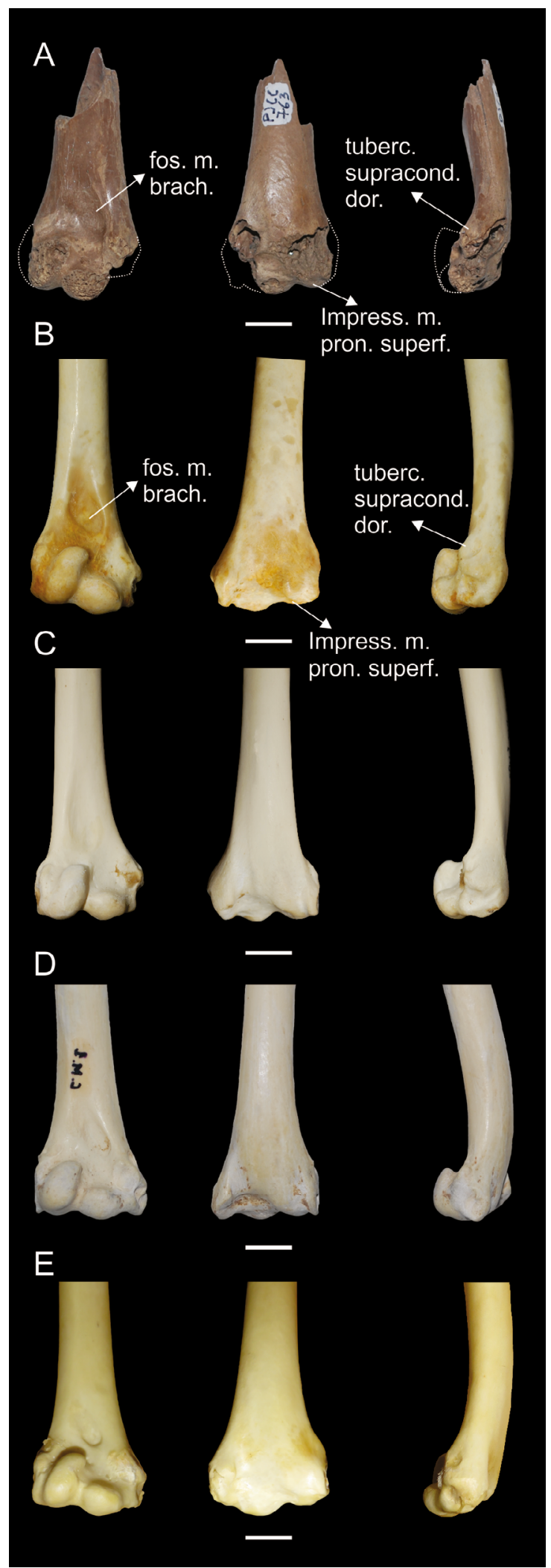

Figure 3. Humerus of the fossil Coscoroba swan compared with the humeri of living Anatidae in cranial, caudal and medial views. A, CICPSGE 20/21; B, Coscoroba coscoroba (MNHN 7011); C, Cygnus melancoryphus (MNHN 5482); D, Oressochen melanopterus (CICYTTP-AAN 064); E, Chloephaga picta (CFA 194). Abbreviations: fos. m. brach., fossa m. brachialis; Impress. m. pron. superf., Impressio m. pronator superficialis; tuberc. supracond. dor., tuberculum supracondylare dorsale. Scale bars $=10 \mathrm{~mm}$.

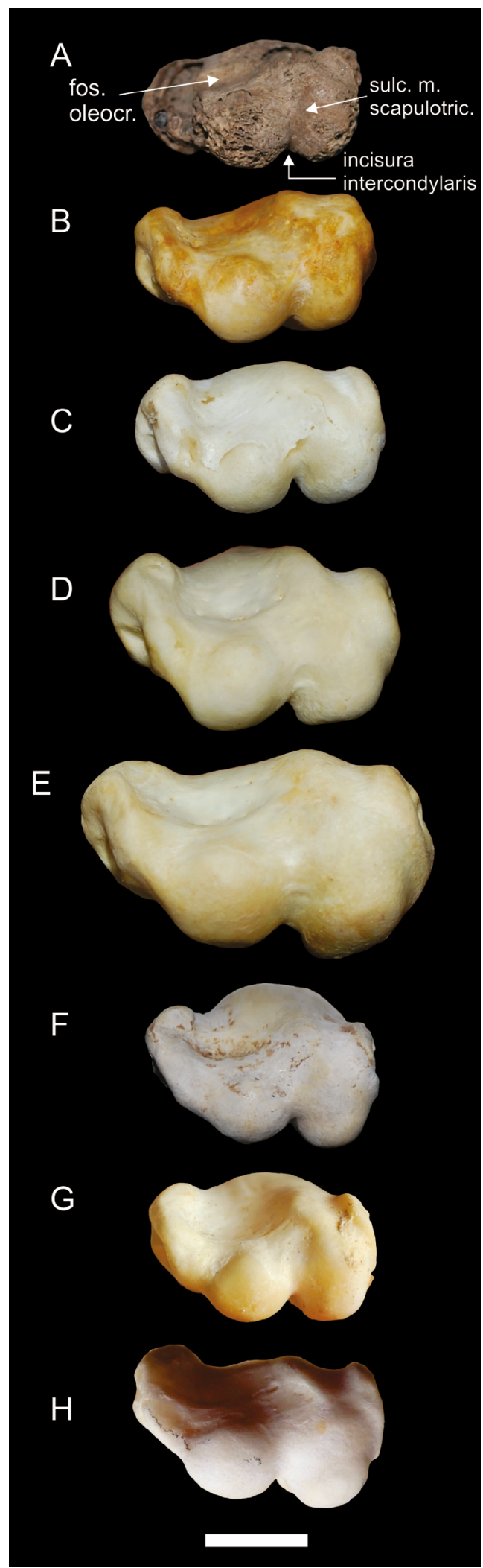

Figure 4. Distal view of the left humeri of living Anatidae compared with CICPSGE 20/21. A, CICPSGE 20/21. B, Coscoroba coscoroba (MNHN 7011). C, Cygnus melancoryphus (MNHN 5482). D, C. atratus (MNHN 6299). E, C. olor (MNHN 7010). F, Oressochen melanopterus (CI). G, Chloephaga picta (MNHN 6309). H, Branta Canadensis (USNM 343185). Abbreviations: fos. oleocr., fossa oleocranialis; sulc. m. scapulotric., sulcus scapulotricipitalis. Scale bar $=10 \mathrm{~mm}$. 
Taphonomic approach. Although not common as other vertebrates, bird remains are relatively frequent in the fossil record of the Pleistocene, with taxa with different guilds such as aquatic, raptor or scavenger birds being represented (Campbell, 1979; Tambussi et al., 2005; Cenizo \& Agnolin, 2007; Cenizo \& Tassara, 2013; Tambussi \& Degrange, 2013; Jones et al., 2021). However, most of the ecological and environmental information from avian fossil remains is lost, because of the unavoidable post-mortem destruction of the bones, or because detailed descriptions of its precise stratigraphic context are not known (Behrensmeyer et al., 2003). In addition, it's possible that the abundance of wing elements, as in this case, is a characteristic of the natural context of deposition (Erickson, 1987). According to this, Livingston (1989) and Cruz (2005) have suggested that the bone structure and functional anatomy of birds are important factors affecting the representation of the skeletal parts in an environment of preservation. Thus, the presence of an aquatic bird from fluvial levels of coarse to medium and fine sands, with known ecological requirements preserved within stratigraphic settings, also allows obtaining information from the taphonomic features on the fossil and from the sedimentological aspects of the fossil bearing deposit. Thus, the new finding provide tools for a better understanding of the paleoenvironment at the time of its deposition.

The potential preservation of bird bones is related to the type of environment they live in, and their burial mainly depends on the substrate where the bones are deposited (Bickart, 1984; Lyman, 1994; Cruz, 2008; Lopes et al., 2019). Fluvial environments, such as continental wetlands, exhibit an important potential for the preservation of fossil birds; in fact, aquatic birds are better represented in the fossil record than the ground-terrestrial species (Mitchell, 2015). The preservation of the specimen CICPSGE 20/21 was probably favored by its association with a depositional environment (i.e. fluvial deposits) and the sedimentological features of the deposits where the fossil comes from (Battaglia, 1982) that improved its preservation, suggesting a likely rapid burial due to increased deposition of sediment by the environment. Considering the prevailing fluvial origin of the sediments, and the evidence of fluvial transport, it is possible that there was a short distance fluvial transport for this remain.

On the other hand, fossil remains of vertebrates that come from the Dulce River Basin; represent a mixture of diverse taxa, mostly Pleistocene mammals, with different ages and states of preservation (Gramajo, 1992; Powell \& Deraco, 2003; Alberdi et al., 2008; Chimento \& Agnolin, 2011; Gaudioso et al., 2017; Albino \& Gaudioso, 2018). These records suggest that the depositional environment is composed of remains from different sources with varying taphonomic histories and probably subject to several episodes of exhumation-transportburial (Behrensmeyer, 1982; Montalvo et al., 2008). Some of these remains (e.g. Chimento \& Agnolin, 2011; Gaudioso et al., 2017), as the Coscoroba swan, show several signs of abrasion (e.g. sharp broken edges in the shaft and abraded irregular surfaces in its distal end). The abrasion, present in the distal end of this fossil, in general suggests fluvial transport
(Aslan \& Behrensmeyer, 1996; Montalvo et al., 2013). Then the mixture of abraded and non-abraded bones could indicate that CICPSGE 20/21 was subjected to different flow regimes (e.g. velocity of the water current).

Shape is also a major factor influencing the transport of bone remains. Bones with irregular shapes have larger surfaces, which increases the potential for transport (Coard \& Dennell, 1995). The fragmented areas of CICPSGE 20/21 are located in structures around its shaft, which suggest that it was transported in a manner similar to forelimbs of some terrestrial vertebrates (Hanson, 1980; Behrensmeyer et al., 2003). The distal end exhibits a more extensive abrasion, which is eroded on the edges of its condylae and only is broken in the epicondyle area (Figure 2). This implies that as the current moved the humerus, it probably rolled uniformly as a cylindrical body, which would have distributed evenly the breaking and abrasion (Lopes \& Ferigolo, 2015). The large form and dimension of this bone probably facilitated its entrainment by flow and its fragmentation would have been the result of several impacts with the bottom of the fluvial environment during its transport (Trapani, 1998; FernándezJalvo \& Andrews, 2003; Montalvo et al., 2013; Tomassini \& Montalvo, 2013).

This novel taphonomic approach, together with the environmental interpretations reported here where the fossil come from, allow us to refer a paleoenvironment associated to wetlands. However, this claim would need to be tested in the austral Chaco and Northern Pampa regions through future multi-proxy studies. On the other hand, this record suggests here a broader geographic distribution during the Late Pleistocene as observed nowadays.

\section{DISCUSSION}

Woolfenden (1961) proposed that Coscoroba is closely related to other swans (Cygnus) than to any other waterfowl, despite some unusual behavioral and morphological characters (Worthy et al., 2017). Based in our results, the general morphology of CICPSGE 20/21 closely resembles the humeri of the living South American forms of the Tribe Cygnini than any other known anatid tribes of ducks. In turn, it is apparent that this fossil is clearly distinguished from large swans, middle geese and small ducks, resembling the osteological morphology of the humerus that Cygnini species possess, which resembles a basal Anserinae duck.

Additionally, living Coscoroba coscoroba have several other features in the humerus that are different from all other geese (i.e. conspicuous tuberculum supracondylare dorsale, shallow tuberculum supracondylare ventrale; deep fossa $\mathrm{m}$. brachialis). Anatomical combination of characters recognized here (Figures 2A-D, 3), together with the linear measurements employed (Table 1), reveal an affinity with the size and shape of the humerus of a basal Coscoroba swan, as follows: (i) fossa $\mathrm{m}$. brachialis large and deeper; (ii) fossa olecrani deep and developed; (iii) condyles ventralis humeri distally developed; (iv) condyles dorsalis humeri with oval shape and separated by a deep incisura intercondylaris; and (v) conspicuous 
Table 1. Humeral measurementes (in mm) of CICPSGE 20/21 and living Anatidae. Abbreviations: w-dist, distal width; w-he, medial humeral condyle width; w-shaft-fb, latero-medial width of the shaft at level of the Fossa m. brachialis; d-shaft-fb, craneo-caudal width of the shaft at level of the Fossa m. brachialis; $\mathbf{p}$, preserved.

\begin{tabular}{|c|c|c|c|c|}
\hline taxon / measurements & w-dist & w-hc & w-shaft-fb & d-shaft-fb \\
\hline CICPSGE 20/21 & $21.33 p$ & $8.25 p$ & 14.15 & 8.28 \\
\hline Coscoroba coscoroba (MNHN 7011) & 23.98 & 11.19 & 13.41 & 8.14 \\
\hline Oressochen melanopterus (AAN 064) & 22.13 & 8.53 & 13.10 & 8.91 \\
\hline Chloephaga picta (MNHN 6306) & 19.75 & 7.45 & 12.40 & 7.14 \\
\hline Sarkidiornis melanotos (MNHN 7087) & 19.43 & 6.69 & 11.37 & 7.47 \\
\hline Cygnus melancoryphus (MNHN 5482) & 23.40 & 8.54 & 12.67 & 7.32 \\
\hline Branta canadensis (USNM 343185) & 26.25 & 9.47 & 20.37 & 17.94 \\
\hline
\end{tabular}

tuberculum supracondylare dorsale. As mentioned, it shares several characters that indicate that it belongs to a swan and more specifically related to Coscoroba coscoroba.

In an overall context for the Quaternary, no anatid swans remains are known for the Middle-Upper Pleistocene in South America. Remains attributed to a Coscoroba were reported by Ameghino (1891) from sediments regarded as Holocene (Platean South American Stage/Age, Cione et al., 2015) in the Pampean plains from Argentina, but without detailed descriptions and precise stratigraphic context, that clearly needs to be confirmed. Currently, another possible record of a basal anserine has recently been reported from Upper Pleistocene deposits from northern Mesopotamia, although a taxonomic assignment other than that of being an Anserinae has not yet been proposed (Cuaranta et al., 2019).

Amongst the Patagonian anatids, only Coscoroba swan has a greater distribution range than the Chloephaga and Oressochen species of sheldgeese described in northward areas (Bulgarella et al., 2014). Its distribution includes a wide range (Figure 5) from Tierra del Fuego to central Chile and northern Argentina, including winters in northern Paraguay, Uruguay, southeastern Brazil, and the Bolivian Chaco (Carboneras \& Kirwan, 2020). It is a common species in all austral open lowlands from Patagonia, even in the Malvinas Islands as a frequent visitor where it occasionally breeds (Madge \& Burn, 1988; Woods \& Woods, 1997; Carboneras \& Kirwan, 2020), living in wetland areas including swamps, shallow lagoons, freshwater marshes, and lakes with abundant vegetation (Fjeldså \& Krabbe, 1990; Denaly \& Scott, 2006).

Fossil bird data have been valued in paleoenvironmental reconstructions (Sánchez-Marco, 1999; Tambussi et al., 2005; Prassack et al., 2017). However, several factors as autoecology, behavior, phylogenetic constrains and anthropogenic impacts in living species distribution must be taken into account and the reliability of studies based on actualist principles have methodological constraints (Nieto \& Rodríguez, 2003).

In this sense, the presence of the extant Coscoroba swan as a fossil record from the Upper Pleistocene in the northwestern of Argentina could be important from a paleoenvironmental standpoint. This taxon could be regarded as an indicator of wetland environments, if its fossils are usually found together with aquatic taxa such as other anatids, ardeids and even associated with other vertebrates such as fish (e.g. Olson \& Rasmussen, 1986; Rasmussen et al., 1987; Diederle \& Noriega, 2013). Although the Coscoroba swan is a permanent austral breeder in the cold Patagonian steppe environments, some individuals migrate to lower latitudes (c. $\left.25^{\circ} \mathrm{S}\right)$ in winter (Carboneras \& Kirwan, 2020). Extant reports of background of this swan outside of its austral range must be considered for a paleoecological interpretation of the record presented in this contribution. Even, this swan was reported in different environments, and there are extant records as a regular visitor to wetlands at the northernmost of it natural range of distribution (around $15^{\circ}-17^{\circ} \mathrm{S}$, Figure 5), between the Pantanal/Cerrado of Brazil (National Park of Chapada dos Guimarães, State of Mato Grosso do Sul, Sick, 1997; Silva, 2018) and the Bolivian Chaco (Camatindi lagoon, Santa Cruz de la Sierra, Tobias \& Seddon, 2007). All this information suggests that some species of swans, as C. coscoroba here, could not have a restricted ecological tolerance, and therefore should not be considered as a reliable paleoclimatic fossil indicator as it was properly applied for some Quaternary geese remains (Tambussi et al., 2005).

\section{ACKNOWLEDGMENTS}

The authors are in debt with invaluable collaboration of curators S. Bogan (Felix de Azara Collection, CFA), C. Milenski (Smithsonian Natural History Museum, USNM), J. González (Museo Nacional de Historia Natural, MNHN) and the ornithological collection of the Vertebrate Paleontology Laboratory of the Centro de Investigación Científica y de Transferencia Tecnológica a la Producción (CICYTTP); for facilitating access to collections of their institutions. We wish to express their gratitude to the family Gaudioso for their support, cooperation and funding the field trips. In addition, we thank the reviewers for providing useful reviews. This work was funded by PICT-ANPCyT 2017-0954 (Argentina), Consejo Nacional de Investigaciones Científicas y Técnias (CONICET, Argentina), and Agencia Nacional de Investigación e Innovación (ANII, Uruguay). 


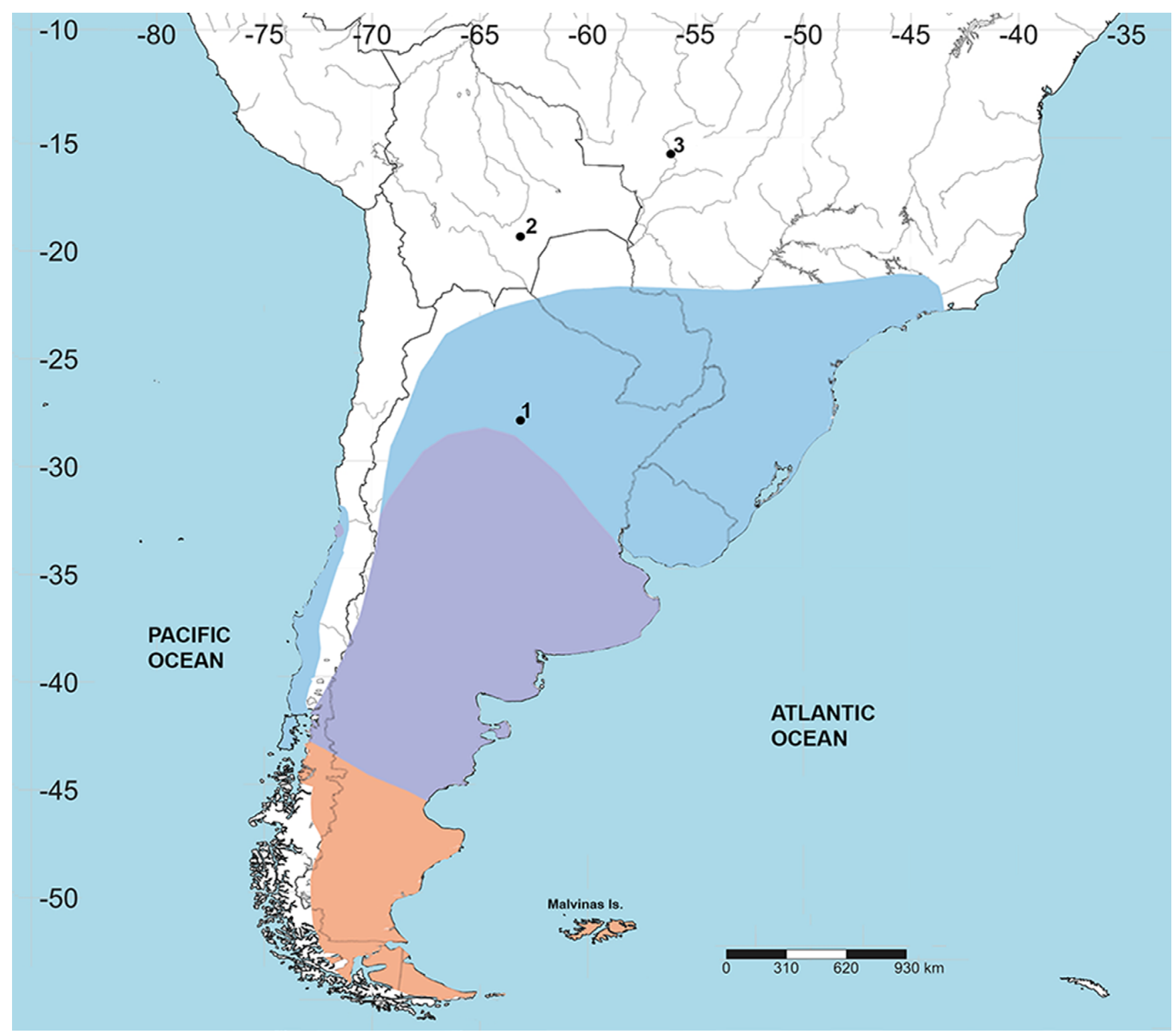

Figure 5. Map showing of the distribution of Coscoroba swan. Lotation of CICPSGE 20/21 (1), living northermost records as a regular visitor from Bolivian Chaco (2) and a regular vistior of Pantanal/Cerrado of Brazil (3). Orange shading represents the natural range of breeding distribution, purpure shading indicates its distribution as a resident all year round, wihle blue shading indicates its ocassional bredding distribution.

\section{REFERENCES}

Acosta Hospitaleche, C.; Jones, W. \& Rinderknecht, A. 2021. Bioerosive traces in a Pleistocene Anatid bone from Uruguay. Journal of South American Earth Sciences, 107:103120. doi:10.1016/j.jsames.2020.103120

Agnolin, F. 2006. Notas sobre el registro de Accipitridae (Aves, Accipitriformes) fósiles argentinos. Studia Geologica Salmanticensia, 42:67-80. doi:10.1016/j.annpal.2012.06.001

Agnolin, F. \& Tomassini, R.L. 2012. A fossil Dendrocygninae (Aves, Anatidae) from the Early Pliocene of the Argentine Pampas and its paleobiogeographical implications. Annales de Paléontologie, 98:191-201.

Alberdi, M.T.; Cerdeño, E. \& Prado, J.L. 2008. Stegomastodon platensis (Proboscidea, Gomphotheriidae) en el Pleistoceno de Santiago del Estero, Argentina. Ameghiniana, 45:257-271.
Albino, A. \& Gaudioso, P.J. 2018. Extant squamates in the Pleistocene of northwestern Argentina. Revista Brasileira de Paleontologia, 21:63-70. doi: 10.4072/rbp.2018.1.04

Ameghino, F. 1891. Enumeración de las aves fósiles de la República Argentina. Revista Argentina de Historia Natural, 1:441-453.

Ameghino, F. 1895. Sur les oiseaux fossiles de Patagonie. Boletin del Instituto Geográfico Argentino, 15:501-602.

Aslan, A. \& Behrensmeyer, A.K. 1996. Taphonomy and time resolution of bone assemblages in a contemporary fluvial system: the East Fork River, Wyoming. Palaios, 11:411-421. doi:10.2307/3515209

Battaglia, A.A.C. 1982. Descripción geológica de las Hojas $13 f$, Río Hondo, $13 \mathrm{~g}$, Santiago del Estero, $14 \mathrm{~g}$, El Alto, $14 \mathrm{~h}$, Villa San Martín, $15 \mathrm{~g}$. Buenos Aires, Servicio Geológico Nacional, 80 p. (Boletín 186).

Baumel, J. \& Witmer, L.M. 1993. Osteologia. In: J. Baumel; J. King; A. Breazile; J.H. Evans \& J. Vanden Berge (eds.) Handbook of 
avian anatomy: Nomina Anatomica Avium, Publications of the Nuttall Ornithological Club, Massachusetts, p. 45-132.

Beder, R. 1928. La Sierra de Guasayán y sus alrededores. Una contribución a la Geología e Hidrogeología de la provincia de Santiago del Estero. Buenos Aires, Ministerio de Agricultura, Dirección General de Minas, Geología e Hidrología, 173 p.

Behrensmeyer, A.K. 1982. Time resolution in fluvial vertebrate assemblages. Paleobiology, 8:211-227. doi:10.1017/ S0094837300006941

Behrensmeyer, A.K.; Stayton, C.T. \& Chapman, R.E. 2003. Taphonomy and ecology of modern avifaunal remains from Amboseli Park, Kenya. Paleobiology, 29:52-70. doi:10.1666/0094-8373(2003)029\%3C0052:TAEOMA\%3E2 .0.CO;2

Bickart, K.J. 1984. A field experiment in avian taphonomy. Journal of Vertebrate Paleontology, 4:525-535. doi:10.1080/0272463 4.1984.10012028

Brandoni, D. \& Vezzosi, R.I. 2019. Nothrotheriops sp. (Mammalia, Xenarthra) from the Late Pleistocene of Argentina: implications for the dispersion of ground sloths during the Great American Biotic Interchange. Boreas, 48:879-890. doi:10.1111/bor.12401.

Bulgarella, M.; Kopuchian, C.; Di Giacomo, A.S.; Matus, R.; Blank, O.; Wilson, R.E. \& Mccraken, K.G. 2014. Molecular phylogenyof the South American sheldgeese with implications for conservation of Falkland Islands (Malvinas) and continental populations of the Ruddy-headed Goose Chloephaga rubidiceps and Upland Goose C. picta. Bird Conservation International, 24:59-71. doi:10.1017/S0959270913000178

Campbell, K.E.Jr. 1976. The late Pleistocene avifauna of La Carolina, southwestern Ecuador. In: S.L. Olson (ed.) Collected papers in avian paleontology honoring the 90th birthday of Alexander Wetmore, Smithsonian Contribution of Paleobiology, vol. 27, p. $155-168$.

Campbell, K.E.Jr. 1979. The Non-Passerine Pleistocene avifauna of the Talara Tar Seeps, Northwestern Peru. Royal Ontario Museum, Life Sciences Contributions, 18:1-203.

Carboneras, C. 1992. Family Anatidae (Ducks, Geese and Swans). In: J. del Hoyo; A. Elliott \& J. Sargatal (eds.) Handbook of Birds fo the World, Vol.1., Lynx Edition, p. 536-630.

Carboneras, C. \& Kirwan, G.M. 2020. Coscoroba Swan (Coscoroba coscoroba), version 1.0. In: J. del Hoyo; A. Elliott; J. Sargatal; D.A. Christie \& E. de Juana (eds.) Birds of the World, Cornell Lab of Ornithology. doi:10.2173/bow.cosswa1.01

Castellanos, A. 1924. Contribución al estudio de la paleoantropología argentina. Restos descubiertos en el arroyo Cululú (Pcia. de Santa Fe). Revista de la Universidad Nacional de Córdoba, 11:1-48.

Cenizo, M.M. \& Agnolin, F. 2007. La presencia del género Belonopterus Reichenbach, 1852 (Aves, Charadriidae) en el Pleistoceno de Argentina, con la descripción de Belonopterus lilloi nov. sp. Revista del Museo Argentino de Ciencias Naturales, 9:41-47.

Cenizo, M.M. \& Agnolin, F. 2010. The southernmost records of Anhingidae and a new basal species of Anatidae (Aves) from the lower-middle Miocene of Patagonia, Argentina. Alcheringa: An Australasian Journal of Palaeontology, 34:493-514. doi:10.1080/03115511003793504

Cenizo, M.M. \& Tassara, D., 2013. Nuevos registros fósiles del halcón plomizo (Falco femoralis Temminck, 1822; Falconidae) en el Pleistoceno del centro-este de Argentina. Historia Natural. Tercera serie, 3:13-30.

Chimento, N.R. \& Agnolin, F.L. 2011. Mamíferos del Pleistoceno superior de Santiago del Estero (Argentina) y sus afinidades paleobiogeográficas. Papéis Avulsos de Zoologia, 51:83-100. doi:10.1590/S0031-10492011000600001

Cione, A.L.; Gasparino, G.M.; Soibelzon, E.; Soibelzon L.H. \& Tonni, E.P. 2015. The Great American Biotic Interchange: A South American Perspective. Dordrecht, Heidelberg, New York, London, SpringerBriefs in Earth System Sciences, 97 p.

Coard, R. \& Dennell, R.W. 1995. Taphonomy of some articulated skeletal remains: transport potential in an artificial environment. Journal of Archaeological Science, 22:441-448. doi:10.1006/ jasc.1995.0043

Cohen, K. M.; Finney, S.C.; Gibbard, P.L. \& Fan, J.-X. 2013. The ICS international chronostratigraphic chart. Episodes, 36:199-204. doi:10.18814/epiiugs/2013/v36i3/002

Cruz, I. 2005. La representación de partes esqueléticas de aves. Patrones naturales e interpretación arqueológica. Archaeofauna International Journal of Archaeozoology, 14:69-81.

Cruz, I. 2008. Avian and mammalian bone taphonomy in southern continental Patagonia: A comparative approach. Quaternary International, 180:30-37. doi:10.1016/j.quaint.2007.08.008

Cuaranta, P.; Méndez, C.; Contreras, S.; Agnolin, F.; Luna, C.A.; Miño-Boilini, A.R. \& Zurtia, A.E. 2019. Primer registro de un ave en el Pleistoceno tardío de la provincia de Corrientes, Argentina. In: REUNIÓN DE COMUNICACIONES DE LA ASOCIACIÓN PALEONTOLÓGICA ARGENTINA, 2019. Libro de Resúmenes, La Plata, Buenos Aires, p. 102-103.

Delany, S. \& Scott, D. 2006. Water bird population estimates. 4th Ed. Wageningen, Wetlands International, $239 \mathrm{p}$.

Diederle, J.M. \& Noriega, J.I. 2013. Aves del Mioceno de la Provincia de Entre Ríos, Argentina. In: D. Brandoni \& J.I. Noriega (eds.) El Neógeno de la Mesopotamia Argentina, Asociación Paleontológica Argentina, vol. 14, p. 97-108.

Erickson, P.G.P. 1987. Interpretations of archaeological bird remains: a taphonomic approach. Journal of Archaeological Science, 14:65-75. doi:10.1016/S0305-4403(87)80006-7

Eyton, T.C. 1838. A Monograph on the Anatidae or Duck tribe. Annals and Magazine of Natural History, 1:473-475. doi:10.1080/00222933809496632

Fernández-Jalvo, Y. \& Andrews, P. 2003. Experimental effects of water abrasion on bone fragments. Journal of Taphonomy, 1:147-163.

Fjeldså, J. \& Krabbe, N. 1990. Birds of the high Andes. Copenhagen, Zoological Museum, University of Copenhagen and Apollo Books, 880 p.

Frenguelli, J. 1920. Excursión en los alrededores de Esperanza (Provincia de Santa Fe). Boletín de la Academia Nacional de Ciencias de Córdoba, 24:257-292.

Frenguelli, J. 1932. Perfiles geológicos de las márgenes del río Salado (Santa Fe). Publicaciones Museo Antropológico y Etnográfico, A2:83-97.

Gaudioso, P.J.; Gasparini, G.M.; Herbst, R. \& Barquez, R.M. 2017. First record of the Neolicaphrium recens Frenguelli, 1921 (Mammalia, Litopterna) in the Pleistocene of Santiago del Estero province, Argentina. Papeis Auvlsos de Zoologia, 57:23-29. doi:10.11606/0031-1049.2017.57.03

Gaudioso, P.J.; Pérez, M.J.; Olivares A.I., \& Díaz, M.M. 2019. Paramyocastor diligens (Rodentia, Hystricomorpha) from Las Cañas Formation (Pliocene), northwestern Argentina. Historical Biology, 33:683-688. doi:10.1080/08912963.2019.1657860

Gmelin, J.F. 1789. Caroli a Linné systema naturae per regna tria naturae, secundum classes, ordines, genera, species, cum characteribus, differentiis, synonymis, locis.Tomus Part. II. 
Editio decima tertia, aucta, reformata. G. Emanuel Beer. Lipsiae, p. 501-1032.

Gramajo, A.J. 1992. La fauna del Cuaternario y sus yacimientos en la Llanura Santiagueña. Museo de Ciencias Antropológicas y Naturales "Emilio y Duncan Wagner”, Serie Estudio, 4:75-93.

Hanson, C.B. 1980. Fluvial taphonomic processes: models and experiments. In: A.K. Behrensmeyer \& A.P. Hill (eds.) Fossils in the making - Vertebrate taphonomy and paleoecology, The University of Chicago Press, p. 156-181.

ICC. 2020. International Chronostratigraphic Chart, International Commission on Stratigraphy. AAvailable at http://www. stratigraphy.org/index.php/ics-chart-timescale; accessed on $01 / 2020$.

Ihering, W. von \& Ihering, R. von. 1907. Catalogos da Fauna Brazileira. Vol. 1:i-xxxviii+1-485. As aves do Brazil. São Paulo, Typographica do Diario Official, 485 p.

Iriondo, M.H. 2010. Geología del Cuaternario de Argentina. Santa Fe, Museo Provincial de Ciencias Naturales "Florentino Ameghino". Moglia Ediciones, 437 p.

Jones, W.W.; Rinderknecht, A.; Vezzosi, R.I.; Montenegro, F. \& Ubilla, M. 2021. First report of large cathartids (Aves, Cathartidae) from the late Pleistocene of Uruguay. Journal of South American Earth Science, 102946. doi:10.1016/j. jsames.2020.102946

Latham, J. 1790. Index ornithologicus, Vol. II. London, Sumptibus authoris, p. 467-920.

Leach, W.E. 1820. Eleventh Room. In: Synopsis of the Contents of the British Museum, 17th Edition, London: British Museum p. $65-70$.

Linnaeus, C. 1758. Systema Naturae. Edition Systema naturae per Regna tria naturae, secundum classes, ordines, genera, species, cum characteribus, differentiis, synonymis, locis. 10th Edition. Stockholm, Laurentii Salvii, 824 p.

Liu, G.; Zhou, L.Z. \& Gu, C.M. 2012. Complete sequence and gene organization of the mitochondrial genome of scaly-sided merganser (Mergus squamatus) and phylogeny of some Anatidae species. Molecular Biology Reports, 39:2139-45. doi:10.1007/ s11033-011-0961-5

Livezey, B.C. 1996. A phylogenetic analysis of geese and swans (Anseriformes: Anserinae), including selected fossil species. Systematic Biology, 45:415-50. doi:10.1093/sysbio/45.4.415

Livezey, B.C. 1997. Phylogenetic analyses of basal Anseriformes, the fossil Presbyornis, and the interordinal relationships of waterfowl. Zoological Journal of the Linnean Society, 124:397398. doi:10.1093/sysbio/45.4.415

Livezey, B.C. \& Zusi, R.L. 2006. Higher-order phylogeny of modern birds (Theropoda, Aves: Neornithes) based on comparative anatomy: 1. Methods and characters. Bulletin of Carnegie Museum of Natural History, 37:1-544.

Livingston, S.D. 1989. The taphonomic interpretation of avian skeletal part frequencies. Journal of Archaeological Science, 16:531-541. doi:10.1016/0305-4403(89)90072-1

Lopes, R.P. \& Ferigolo, J. 2015. Post mortem modifications (pseudopaleopathologies) in Middle-Late Pleistocene mammal fossils from Southern Brazil. Revista Brasileira de Paleontologia, 18:285-306. doi:10.4072/rbp.2015.2.09

Lopes, R.P.; Pereira, J.C. \& Ferigolo, J. 2019. A late Pleistocene fossil stork (Ciconiformes: Ciconiidae) from the Santa Vitória Formation, southern Brazil and its paleonvironmental significance. Revista Brasileira de Paleontologia, 22:199-216. doi:10.4072/rbp.2019.3.03
Lyman, R.L. 1994. Vertebrate Taphonomy. Cambridge, Cambridge University Press, $524 \mathrm{p}$.

Madge, S. \& Burn, H. 1988. Waterfowl: an identification guide to the ducks, geese, and swans of the world. New York, Houghton Mifflin Company, 298 p.

Mayr, G. 2017. Avian evolution: the fossil record of birds and its paleobiological significance. Chichester, John Wiley and Sons, Wiley-Blackwell, 306 p.

Mitchell, J.S. 2015. Preservation is predictable: quantifying the effect of taphonomic biases on ecological disparity in birds. Paleobiology, 41:353-367. doi:10.1017/pab.2014.23

Molina, J.I. 1782. Saggio sullla Storia Naturale del Chili, Bologna, Nella Stamperia di S. Tommaso d'Aquino, $367 \mathrm{p}$.

Montalvo, C.I.; Melchor, R.N.; Visconti, G. \& Cerdeño, E. 2008. Vertebrate taphonomy in loess-palaeosol deposits: A case study from the late Miocene of central Argentina. Geobios, 41:133-143. doi:10.1016/j.geobios.2006.09.004

Montalvo, C.I.; Zárate, M.A.; Bargo, M.S. \& Mehl, A. 2013. Registro faunístico y paleoambientes del Cuaternario tardío, provincia de La Pampa, Argentina. Ameghiniana, 50:554-570. doi:10.5710/ AMGH.21.09.2013.703

Nieto, M. \& Rodríguez, J. 2003. Inferencia paleoecológica en mamíferos cenozoicos: limitaciones metodológicas. Coloquios de Paleontología, 1:459-474.

Noriega, J.I.; Tambussi, C.P. \& Cozzuol, M.A. 2008. New material of Cayaoa bruneti Tonni, an early Miocene anseriform (Aves) from Patagonia, Argentina. Neues Jahrbuch fur Geologie und Palaeontologie, 249:271-280. doi:10.1127/00777749/2008/0249-0271

Olson, S.L. \& Rasmussen, D.T. 1986. The paleoenvironment of the earliest hominoids: new evidence from the Oligocene avifauna of Egypt. Science, 233:1202-1204. doi:10.1126/ science.233.4769.1202

Powell, J.E. \& Deraco, M.V. 2003. Mamíferos Pleistocenos del Río Dulce, provincia de Santiago del Estero. Implicancias cronológicas. In: JORNADAS ARGENTINAS DE MASTOZOOLOGÍA, 18, 2003. Libro de Resúmenes, La Rioja, Sociedad Argentina para el Estudio de los Mamiferos, p. 30.

Prassack, K.A.; Pante, M.C.; Njau, J.K. \& de la Torre, I. 2017. The paleoecology of Pleistocene birds from Middle Bed II, at Olduvai Gorge, Tanzania, and the environmental context of the Oldowan-Acheulean transition. Journal of Human Evolution, 120:32-47. doi:10.1016/j.jhevol.2017.11.003

Rasmussen, D.T.; Olson, S.L. \& Simons, E.L. 1987. Fossil birds from the Oligocene Jebel Qatrani Formation, Fayum Province, Egypt. Smithsonian Contributions to Paleobiology, 62:1-20. doi:10.5479/si.00810266.62.1

Remsen, J.V.Jr.; Areta, J.I.; Bonaccorso, E.; Claramunt, S.; Jaramillo, A.; Pacheco, J.F.; Robbins, M.B.; Stiles, F.G.; Stotz, D.F. \& Zimmer, K.J. 2020. A classification of the bird species of South America. American Ornithological Society. Available at http:// www.museum.lsu.edu/ Remsen/SACCBaseline.htm accessed on $01 / 08 / 20$.

Reichenbach, H.G.L. 1852. Avium systema naturale, Dresden und Leipzig, Expedition der vollständigsten naturgeschichte, 100 p.

Sánchez-Marco, A. 1999. Implications of the avian fauna for paleoecology in the Early Pleistocene of the Iberian Peninsula. Journal of Human Evolution, 37:375-388.

Sick, H. 1997. Ornitologia Brasileira, Rio de Janeiro, Editora Nova Fronteira, $862 \mathrm{p}$. 
Silva, N.A. 2018. WA3033090, Coscoroba coscoroba (Molina, 1782). Wiki Aves - A Enciclopédia das Aves do Brasil. Available at http://www.wikiaves.com/3033090; accessed on 29/07/2020.

Sun, Z.; Pan, T.; Hu, C.; Sun, L.; Ding, H.; Wang, H.; Zhang, C.; Jin, H.; Chang, Q.; Kan, X \& Zhang, B. 2017. Rapid and recent diversification patterns in Anseriformes birds: Inferred from molecular phylogeny and diversification analyses. PLOS ONE, 12:e184529. doi:10.1371/journal.pone.0184529

Swainson, W. 1837. On the Natural History and Classification of Birds, London, Logman and Ress, 365 p.

Tambussi, C.P. 1998. Nuevo Anatidae (Aves: Anseriformes) del Plioceno de la region pampeana, Argentina. Bolleti de la Societat d'Història Natural de les Balears, 41:19-25.

Tambussi, C. \& Degrange, F.J. 2013. South American and Antarctic continental Cenozoic birds - Paleobiogeographic affinities and disparities. Dordrecht, Springer, 113 p. doi:10.1007/978-94007-5467-6

Tambussi, C.; Ubilla, M.; Hospitaleche, C.A. \& Perea, D. 2005. Fossil records and paleoenvironmental implications of Chloephaga picta (Gmelin, 1789) (Magellan Goose) and Cariama cristata (Linnaeus, 1766) (Seriema) from the Late Pleistocene of Uruguay. Neues Jahrbuch für Geologie und Paläontologie, 5:257-268. doi:10.1127/njgpm/2005/2005/257

Tobias, J.A. \& Seddon, N. 2007. Ornithological notes from southern Bolivia. Bolletin of British Ornithologists ' Club, 127:293-300.

Tomassini, R.L. \& Montalvo, C.I. 2013. Taphonomic modes on fluvial deposits of the Monte Hermoso Formation (early Pliocene), Buenos Aires Province, Argentina. Palaeogeography, Palaeoclimatology, Palaeoecology, 369:282-294. doi:10.1016/j. palaeo.2012.10.035

Tonni, E.P. 1969. La presencia de Anas leucophrys (Aves: Anseriformes) en sedimentos de edad Ensenadense (Pleistoceno medio) de la provincia de Buenos Aires. Ameghiniana, 6:309-313.

Trapani, J. 1998. Hydrodynamic sorting of avian skeletal remains. Journal of Archaeological Science, 25:477-487. doi:10.1006/ jasc.1997.0257

Vallone, E.; Vezzosi, R.I. \& Cione, A. 2017. First fossil fish (Teleostei, Siluriformes) from the Late Pleistocene of Santa Fe Province, Argentina. Alcheringa, 41:369-377. doi:10.1080/03 115518.2017.1288828
Vezzosi, R.I. 2016. Diversidad de los mamíferos del Pleistoceno de la Provincia de Santa Fe, Argentina: aspectos taxonómicos, bioestratigráficos y paleobiogeográficos relacionados. Mastozoología Neotropical, 23:215-217.

Vezzosi, R.I.; Brunetto, E. \& Flores, D. 2017. An intertropical Opossum (Mammalia, Marsupialia, Didelphidae) from the late Middle-Late Pleistocene of austral South America. Historical Biology, 31:181-195. doi:10.1080/08912963.2017.1354181

Vezzosi, R.I.; Brunetto, E. \& Zalazar, M.C. 2019. El registro fósil de vertebrados del Cuaternario de Santa Fe (Argentina): primera Actualización. In: N. Nasiff; G. Esteban; J. Chiesa; A. Zurita \& S. Georgieff (eds.) Mioceno al Pleistoceno del centro y norte de Argentina, Opera Lillioana 52, p. 638-670.

Vieillot, L.J.P. 1816. Nouveau dictionnaire d' histore naturelle. nouv. éd., 14: $222 \mathrm{p}$.

Vigors, N.A. 1825. Observations on the natural affinities that connect the orders and families of birds. Transactions of the Linnean Society of London, 14:395-517.

Wagler, J. 1831. Einige Bemerkungen über Thiere Mexicos. In: Isis, oder Encyclopaedische Zeitung von Oken, Nr. V, p. 510-531.

Woods, R.W. \& Woods, A. 1997. Atlas of breeding birds of the Falkland Islands. Oswestry, Anthony Nelson, 193 p.

Woolfenden, G.E. 1961. Postcranial osteology of the waterfowl. Bulletin Florida State Museum, Biological Sciences, 6:1-129.

Worthy T.H. 2008. Tertiary fossil waterfowl (Aves: Anseriformes) from Australia and New Zealand. Unpublished Ph.D. thesis, School of Earth and Environmental Sciences, University of Adelaide, Australia, 407 p.

Worthy T.H.; Degrange, F.J.; Handley, W.D. \& Lee, M.S.Y. 2017. The evolution of giant flightless birds and novel phylogenetic relationships for extinct fowl (Aves, Galloanseres). Royal Society Open Science, 4:170975. doi:10.1098/rsos. 170975

Received in 18 January, 2021; accepted in 05 September, 2021. 